\title{
アルミナ長繊維を用いた複合インペラーの 開発
}

Synopsis :

Recently, fiber-reinforced metal (FRM) has called much attention in various fields of industry where high strength-to-weight ratios are requied, such as jet-engine parts and structure members of aircraft. In order to fabricate alumina-fiber/aluminum composite, we tried to develop a method to incorporate molten aluminum alloy into reinforcing fibers by pressurized casting method. This method was applied to investment moulds for precision castings, and consequently complex and large composite products, such as impellers, were produced more easily than conventional method.

In this paper we investigated desired properties of alumina-fiber/aluminum a composite impeller for gas turbine engines and manufacturing method. Prototype impeller had good composite structure and improved tensile strength. But the results were not satisfactory enough.

Key words : composite ; alumina-fiber ; impeller ; jet-engine ; aluminum.

\section{1. 緒}

言

䋐維強化金属（FRM : Fiber Reinforced Metal）につ いては，今後さらに開発が進み応用分野が広がるものと 思われるが，特にこの中でも航空機やジェットエンジン 用の材料としての進展が大きく期待されている122). FRM が塞用材料としてょり多く利用されていくには, 力学的特性がより向上すると共に二次成形加工技術も含 めて経済的に優れた製造法が確立されることが不可欠で ある。しかし，現在の FRM 製造法の多くは，複雑な形 状を有する製品を得るのには適当でないのが実状であ る.

そこで著者らは複雑形状の製品を得るのに最も適して いる精密鋳造法を，FRMの製造に応用することができ ればより多くの実用部品にこれを活用していくことがで きると考えその基䃈的製造条件を検討した。

そして FRM の採用による軽量化で, 航続距離などの 性能が大きく向上することが期待される小型ジェットエ ンジン用インペラーの試作を行ったので, その詳細につ いて報告する。

\section{2. 複合インペラーの基本概念}

\section{$2 \cdot 1$ 軽量化効果}

Photo. 1のような構造のジェットエンジンの中でイ ンペラーは燃燒器の前にあり, その回転により外部から 空気を取り入れ压縮して燃焼器へ送る役割を持つ. ジェットエンジンにおいて部材の軽量化を行うことは燃 料経済性と航続性能を向上させるために極めて重要であ り, 中でもインペラーのような回転部材は軽量化の効果 が大きい3).

いま Photo. 1 の小型航空機用の 1 軸ターボジェット

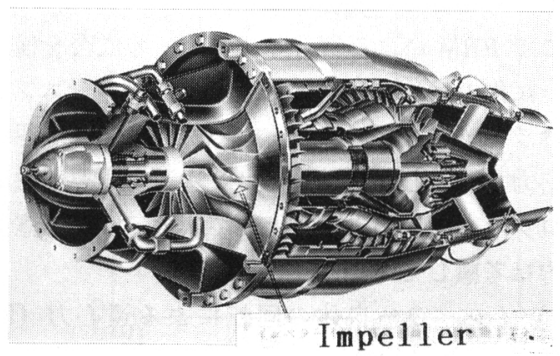

Photo. 1. Structure of turbo-jet engine and impeller. 
エンジン（圧縮器 1 段地上静止時推力 $1470 \mathrm{~N}$ 乾燥重量 $\left.40 \mathrm{~kg}^{4)}\right)$ で，現用のステンレス鋳龬製インペラーをアル ミニゥム合金で製造すると，その重量は約 $2 \mathrm{~kg}$ となり 現状より約 $3.3 \mathrm{~kg}$ （エンジン全体としては約 $8 \%$ ）の軽 量化となる．そしてこれはジェットエンジン本体に，次 のような性能の向上をもたらす。

（1）減量分 $3.3 \mathrm{~kg}$ 相当の装備を新たに搭載できる. 例えば燃料を $3.3 \mathrm{~kg}$ 分多く搭載できると, 高度 $1000 \mathrm{~m}$, 速度マッハ 0.9 の最大出力の状態で $12 \%$ 運転時間が延 長できる.

（2）回転軸周りの慣性モーメント（Iz）が約 $64 \%$ に 減少するので，エンジンの加速時間も現在の $64 \%$ に短 縮できる.

（３）ベアリング,ベアリングサポートの担力荷重も 低隇できる.

このようにインペラーの材質をアルミニウム合金に変 更できれば,エンジン本体で大きな性能向上が得られる. しかしこのジェットエンジンでは運転時のインペラーの 表面温度が最大 $180^{\circ} \mathrm{C}$ に達し, 従来のアルミニウム合 金ではこの温度付近の強度が低いため回転により発生す る応力に耐えられず，実際に材料の変更を行うのは不可 能であった。

これに対し例えば炭素䄉維などを用いたアルミニウム 基 FRM は, 常温での強度が高いばかりでなく $300^{\circ} \mathrm{C}$ 付近までの温度範囲で強度低下が小さく, 比重の点では アルミニゥム合金とほとんど変わらないため, 上述のイ ンペラーの軽量化が可能である.

\section{$2 \cdot 2$ 応力解析}

インペラーのような回転部材で, 使用材料の機械的性 質を評価する際には揰力を密度で割った值が指標として 用いられる. FRM がこのインペラーの材料として使用 できるには，運転時の最高温度である $180^{\circ} \mathrm{C}$ までこの 比が, 現在の材質である析出硬化型ステンレス鋳鋼と同 等以上であることが前提となる.

そこで FRM による複合インペラーの成否を検討する ため, 試作の対象とした 1 軸ターボジェットエンジン用 インペラー（最大径 $196 \mathrm{~mm}$, 翼枚数 17）の, 回転時の 発生応力を計算した. 計算には 2 次元有限要素法応力解 析プログラムを用い，荷重として次の二つを考慮した。 熱応力は考慮していない。

（1）インペラー自体の回転による遠心力（回転数 $53000 \mathrm{rpm}$, 周速 $490 \mathrm{~mm} / \mathrm{s}$ )

（2）インペラーブレードによる外力

計算に必要な物性値がアルミニウム合金基の FRM に ついては十分に明らかになっていないので，アルミニウ

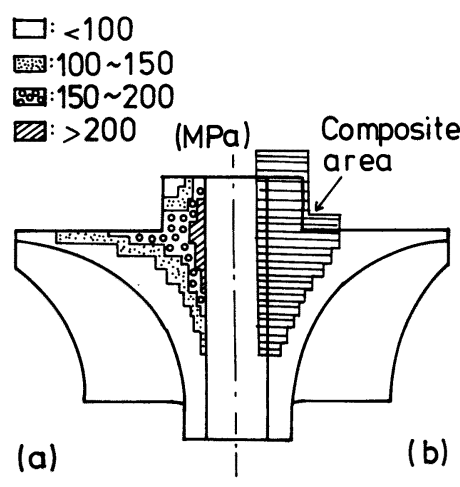

(a) Distribution of Mises equivalent stress

(b) Composite area

Fig. 1. Results of stress analysis of impeller and composite area.

Table 1. Impeller descpription.

\begin{tabular}{l|c|c}
\hline & Conventional impeller & Composite impeller \\
\hline Material & $17-4 \mathrm{PH}$ stainless steel & Fiber/aluminum composite \\
Density $(D)$ & $7.8 \times 10^{3} \mathrm{~kg} / \mathrm{m}^{3}$ & $2.7 \sim 3.2 \times 10^{3} \mathrm{~kg} / \mathrm{m}^{3}$ \\
Weight & $5.3 \mathrm{~kg}$ & $\leqq 2.0 \mathrm{~kg}$ \\
Yield & $>1098 \mathrm{MPa}$ & Disk $>490 \mathrm{MPa}$ \\
strength $(Y)$ & & Blade $>196 \mathrm{MPa}$ \\
$\begin{array}{l}\text { Strength } \\
\text { ratio }(Y / D)\end{array}$ & $10.8 \times 10^{6} \mathrm{~mm}$ & Disk $>15.6 \times 10^{6} \mathrm{~mm}$ \\
& & Blade $>7.4 \times 10^{6} \mathrm{~mm}$ \\
\hline
\end{tabular}

厶合金 $\mathrm{AC} 4 \mathrm{C}$ (密度 $2.68 \times 10^{3} \mathrm{~kg} / \mathrm{m}^{3}$, 縦弾性係数 $7.35 \times 10^{3} \mathrm{MPa}$ ，ポアソン比 $0.33 ）$ の值を使用した.

計算結果のインペラーの軸方向の断面でのミーゼス型 相当応力の分布の概略を, Fig. 1 (a) に示す. 応力の発 生軸方向は主に半径方向と円周方向で, 最大応力は 262 $\mathrm{MPa}$ であった.

\section{$2 \cdot 3$ 必要特性と候補材料}

応力解析結果からアルミニゥム基 FRM の密度を $3.00 \times 10^{3} \mathrm{~kg} / \mathrm{m}^{3}$ と仮定し設計上の安全率を 2.0 とし て, 複合インペラーの目標とする特性を Table 1のよう に設定した。この材料特性に対し，現在まで公表されて いるアルミニウム基 FRM は引張強さ $500 \sim 1000 \mathrm{MPa}$ で比強度が $20 \sim 30 \times 10^{6} \mathrm{~mm}$ の範囲にあり ${ }^{1)} \mathrm{FRM}$ では 引張強さと耐力が近い值を持つのでこの持性を满足する ことができるものと考えられる.

FRM に使用する綫維材料としては，炭素綫維，アル ミナ織維, 炭化けい素綫維, 、ボロン織維などの長織維や 各種短䄉維, さらにウイスカーなども検討されているが, 今回の開発では後述の製造条件の検討を進める中でアル ミニウム合金との濡れ性が良く，しかもプリフォームの 作製に適した形で供給されているアルミナ長䄉維（住友 化学工業株式会社製）を選定した。 
Table 2. Properties of alumina fiber

\begin{tabular}{l|c}
\hline Crystal phase & Spinel $(\gamma)$ \\
Chemical composition & $85 \mathrm{wt} \%$ \\
$\mathrm{Al}_{2} \mathrm{O}_{3}$ & $15 \mathrm{wt} \%$ \\
$\mathrm{SiO}_{2}$ & $3.2 \times 10^{3} \mathrm{~kg} / \mathrm{m}^{3}$ \\
$\begin{array}{c}\text { Physical properties } \\
\text { Density }\end{array}$ & $17 \mu \mathrm{m}$ \\
Filament characteristics & Continuous \\
Diameter & 380 \\
Filament length & \\
Filament/yarn \\
Mechanical properties \\
Tensile strength \\
Tensile modulus & $1.8 \mathrm{GPa}$ \\
Thermal properties & $210 \mathrm{GPa}$ \\
Max. use temperature & $1250^{\circ} \mathrm{C}$ \\
Coef. of thermal expansion & $8.8 \times 10^{-6} /{ }^{\circ} \mathrm{C}$ \\
\hline
\end{tabular}

このアルミナ緎維の特性は Table 2に示すとおりであ るが, 特に複合材への応用を考えた時には以下の特徴を 有している5).

（1）空気中では高温まで安定であり，1000 C で長 時間保持しても特性の劣化は少ない.

（2）溶融金属に侵されにくい.

（3）織布などの加工が可能である.

\section{$2 \cdot 4$ 部分複合化領域の検討}

応力解析結果によれば, 発生する応力の高いのはイン ペラーのボス部の中心部で, 一方翼部は応力は低く, 形 状が複雑で織維の配列も難しい．そこで複合化は応力が 高く強化が必要なボス部の中心部のみ行うこととし，そ の領域を Fig. 1 (b) のように設定した.

\section{3. 雾囲気加圧鋳造法}

\section{$3 \cdot 1$ 新製造法のねらい}

スクイズキャスト法による複合材の製造では，溶融金 属に50〜100 MPa の圧力をかけ配列した㵶維間に浸透 させ複合化させるが6)，複合材料の製造法の中では比較 的複雑な形状の部材が得られるとされている. しかし， 使用する圧力が大きいため鋳型として金型を用いる必要 があり，3 次元的形状の翼部を持つインペラーを製造す るのは難しい面が多い．また圧力が大きいため，大型の 設備が必要となる点も問題である7).

そこで今回の複合インペラーの製造には，新しい複合 化法の開発が必要であった.

福永らによると, アルミニウム合金と炭化けい素 ( $\mathrm{SiC})$ 綫維のスクイズキャスト法による複合化で, 実 際に溶湯が䄉維間に浸透するのに必要な圧力は $1 \mathrm{MPa}$ 以下である ${ }^{8)}$. 一方このインペラーのような複雑形状の 部材は, 一般にセラミックスシェル鋳型を用いた精密鋳 造法により製造される.

そこで筆者らはこの二つを考えあわせた， ガスの加圧
による複合化方法に着目した.これは䄉維の周りの溶融 金属を，雲囲気ガスの加圧により䄉維間に浸透させ複合 化を得ようとするもので，使用する圧力が低く静水圧な ので, 金型に代わりセラミックスシェル鋳型を使用する ことが可能となり，インペラーのような複雑な形状を有 する部材も，容易に製造することができる.

\section{$3 \cdot 2$ 複合化条件の検討}

ガス加圧により複合材を製造するためには, 加圧力と 䄉維の予熱温度が複合化にどのような影響を及ほすかを 把握し，その製造条件を確立する必要がある．今回はガ 压を安全上 $0.98 \mathrm{MPa}$ 以下に限定したので, 織維の予 熱温度と複合化の関係を中心に実験を行った。

溶湯が織維間に含浸していく過程で溶湯の凝固が進行 すれば, 複合化は得られない. そこで緎維の予熱温度を 高くして浸透距離を伸ばすことが, 加圧力が小さく溶湯 が織維間に浸透する速度も小さい場合には重要であ る9). しかし, 予熱温度が高くなると織維の劣化が起こ り, 複合材の強度が低下することがある.このため予熱 温度は複合可能な範囲で，できるだけ低く抑えることが 重要である.

実験では $0.9 \mathrm{MPa}$ のガスの圧力を用いて複合化に必 要な繊維及び鋳型の予熱条件を, 使用するアルミナ織維 の劣化が少ない $1000^{\circ} \mathrm{C}$ までの範囲で検討した.内径 $24 \mathrm{~mm}$, 長さ $200 \mathrm{~mm}$ のアルミナ製の小型るつぼの中に, アルミナ綫維を $100 \mathrm{~mm}$ 長さで一方向に配列し，これを 各温度で $1 \mathrm{~h}$ 予熱して加圧容器中に置いた.つぎに純ア ルミニウムの溶湯をるつほ上部に入れた後, 容器内を窒 素により加圧した．溶湯温度は $700 〜 750^{\circ} \mathrm{C}$ であった. これらの実験結果を整理した, 予熱温度および加圧力と 複合化との関係を Fig. 2 に示す.これにより加圧力

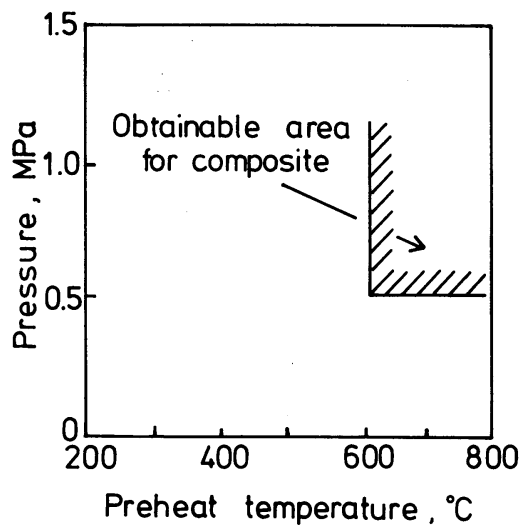

Fig. 2. Obtainable condition (preheat temperature and pressure) for composite. 


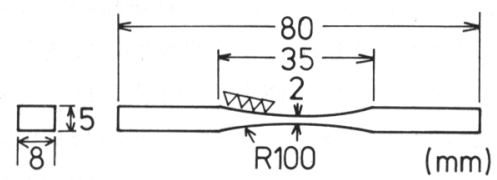

Fig. 3. Shape and dimension of tensile test specimen.

$0.49 \mathrm{MPa}$ 以上, 予熱温度 $600^{\circ} \mathrm{C}$ 以上の条件で, アルミ ナ繊維と純アルミニウムとの複合材が得られることが明 らかになった。

次に加圧力 $0.9 \mathrm{MPa}$, 予熱温度 $800^{\circ} \mathrm{C}$ の条件で製造 した，純アルミニウム基の複合材から，Fig. 3 に示す形 状の引張試験片を作成し機械的性質を測定した。得られ

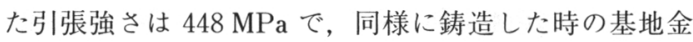
属の引張強さ $56 \mathrm{MPa}$ と比較して繊維強化による大きな 強度の上昇が認められた。この試料の金属組織を 1 視野 $0.4 \times 0.3 \mathrm{~mm}$ で 50 視野画像解析装置を用いて観察した ところ, 緎維体積率は平均 $41.4 \%$ であった.

これらの実験結果から，今回考案した製造法（以下， 雲囲気加压鋳造法と呼ぶ）により，特性の優れたアルミ ニウム基複合材料が製造できることが明らかになった。 この新しい䨌囲気加圧鋳造法には，以下の特徽がある，

（1）精密鋳造鋳型を使用できる.

( 2 ）高価な大型の装置を必要としない.

（３）複雑な形状や大型の部品の製造が可能である。

\section{4. 複合インペラーの製造}

\section{$4 \cdot 1$ プリフォームの作製}

強化繊維は長繊維でその強さは一軸方向のみに発揮さ れるが，発生する応力は場所によりその主方向と大きさ が変化するので，全体を通じて応力の小さな回転軸方向 を除いては，繊維の配列には等方性を持たせる必要があ る. そこで 2 次元的に擬似等方体となるように $60^{\circ}$ おき に緎維を配列した Fig. 1（b）の形状のプリフォームを 以下のように製作した。

一方向に配列した緎維を熱硬化性樹脂により接着した 平均緎維体積率 $50 \%$ のプレシート $(250 \mathrm{~mm}$ 角, 厚さ $250 \mu \mathrm{m})$ を, $60^{\circ}$ 配列で 12 枚積み重ねて $200 \sim 230^{\circ} \mathrm{C}$ でホットプレスし, 厚さ約 $3.5 \mathrm{~mm}$ の擬似等方体を得た. そしてこれより複合化領域にあわせて 21 枚の円盤を切 断して積み重ね，全体をステンレス製の治具により固定 した.

プレシートの切断については YAG レーザーによる方 法と, ウォーター・ジェットを用いる方法を比較検討し

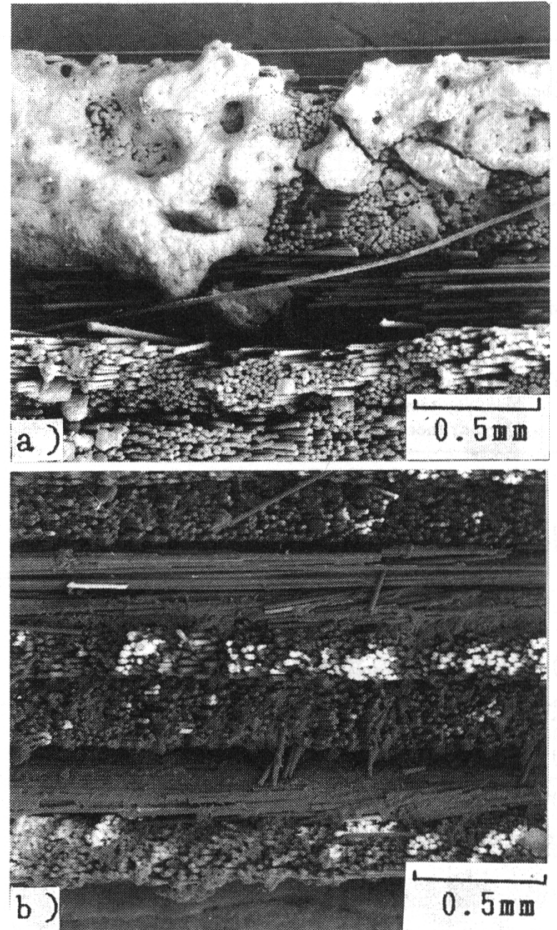

a) Cut by YAG Laser b) Cut by water jet

Photo. 2. Scanning electron micrographs of cross section of alumina-fiber presheet.

た. Photo. 2 にプレシートの切断面の走査型電子顕微 鏡の観察結果を示す。レーザーによる切断面では繊維や 有機バインダーの一部が溶融し, 切断面をその残㳯が 覆っている.このような状態ではアルミニウム合金の溶 湯の繊維間への浸透が妨げられ，また切断面と基地部と が密着せず十分な強度が得られない。一方ウォーター・ ジェットを用いた場合にはこのような残滓はみられず, 切断面と溶湯との濡れ性も良好であった，従って今回の プレシートの切断には,この方法を採用した。

\section{$4 \cdot 2$ 基地合金の選定}

複合インペラーの基地合金として最適なアルミニウム 合金を選定するため, $3 \cdot 2$ の予備的検討と同様の小型る つぼを用いる方法で得た鋳造用アルミニウム合金とアル ミナ繊維を複合化した試料から, Fig. 3 に示す形状の試 験片を加工し引張試験を行った。対象とした合金は $\mathrm{Al}-\mathrm{Cu}-\mathrm{Mg}$ 合金 (AC1A), Al-Si-Cu-Mg 合金 (AC 4 B), $\mathrm{Al}-\mathrm{Si}-\mathrm{Mg}$ 合金（AC 4 C) の 3 種である. な拈製造条件 の検討で使用した純アルミニウムは単独では強度が低 く，また実際の鋳造には適さないことから除外した。 
Table 3. Tensile strength of alumina-fiber/aluminum composite.

\begin{tabular}{|c|c|c|c|c|c|}
\hline \multirow{2}{*}{ Alloy } & \multicolumn{3}{|c|}{ Chemical composition (wt \%) } & \multirow{2}{*}{$\begin{array}{c}\text { Heat } \\
\text { treatment }\end{array}$} & \multirow{2}{*}{$\begin{array}{c}\text { Tensile } \\
\text { strength } \\
\text { (MPa) }\end{array}$} \\
\hline & $\mathrm{Cu}$ & $\mathrm{Si}$ & $\mathrm{Mg}$ & & \\
\hline $\mathrm{AClA}$ & 4.80 & 0.07 & 0.16 & $\overline{\mathrm{T} 6}{ }^{*}$ & $\begin{array}{l}375 \\
446\end{array}$ \\
\hline $\begin{array}{l}\text { AC4B } \\
\text { AC4C }\end{array}$ & $\begin{array}{l}2.30 \\
0.25\end{array}$ & $\begin{array}{l}8.41 \\
7.04\end{array}$ & $\begin{array}{l}0.34 \\
0.16\end{array}$ & $\overline{\mathrm{T} 6^{* 2}}$ & $\begin{array}{l}165 \\
223 \\
275\end{array}$ \\
\hline
\end{tabular}

* $\mathrm{AC} 1 \mathrm{~A}-\mathrm{T} 6510^{\circ} \mathrm{C}, 8 \mathrm{~h}$, water quench $155^{\circ} \mathrm{C}, 20 \mathrm{~h}$, air cool

*2 $\mathrm{AC} 4 \mathrm{C}-\mathrm{T} 6510^{\circ} \mathrm{C}, 8 \mathrm{~h}$, water quench $155^{\circ} \mathrm{C}, 20 \mathrm{~h}$, air cool

Table 4. Manufacturing condition of aluminafiber/aluminum composite impeller.

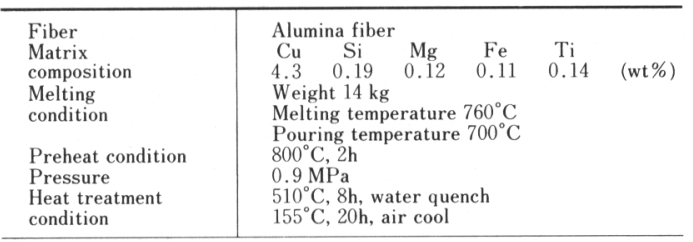

複合化条件はすべて圧力 $0.9 \mathrm{MPa}$, 予熱温度は $800^{\circ} \mathrm{C}$ とし, 注湯時に鋳型と繊維の温度が複合化に必要 な $600^{\circ} \mathrm{C} よ り$ 低下することがないように配虑した。ま た注湯時の溶湯温度は $720 \sim 730^{\circ} \mathrm{C}$ であった。 $\mathrm{AC} 1 \mathrm{~A}$ および AC 4 C については, 溶体化処理焼入れおよび焼 もどし（T 6 処理）を実施した.

引張試験の結果を Table 3 に示す。この結果から最 高の引張強さが得られた AC $1 \mathrm{~A}-\mathrm{T} 6$ 材を, 複合インペ ラーの基地合金に採用した.

\section{$4 \cdot 3$ 複合インペラーの製造}

以上のようなプリフォームの作製と基地合金の選定結 果をもとに，雲囲気加圧鋳造法により複合インペラーの 試作を行った。製造条件を Table 4 に，製造工程を以 下に示す.

（1）セラミックスシェル鋳型の所定の位置に, アル ミナ長瀻維のプリフォームを固定する.

（2）鋳型を予熱する.ここでプリフォーム中の樹脂 は除去される。

（３）予熱した鋳型を加圧容器中にセットし，アルミ ニウム合金を注湯する。

（4）注湯後ただちに加圧容器を閉め, 窒素で加圧し 凝固終了まで保持する。

\section{$4 \cdot 4$ 複合インペラーの特性}

製造したインペラーの中央部を切断した状況を， Photo. 3 に示す。擬似等方体に成形したプリフォーム 中に溶湯が十分含浸しており，また翼の先端への湯回り も良好で鋳物としてほぼ完全な物が得られている，断面

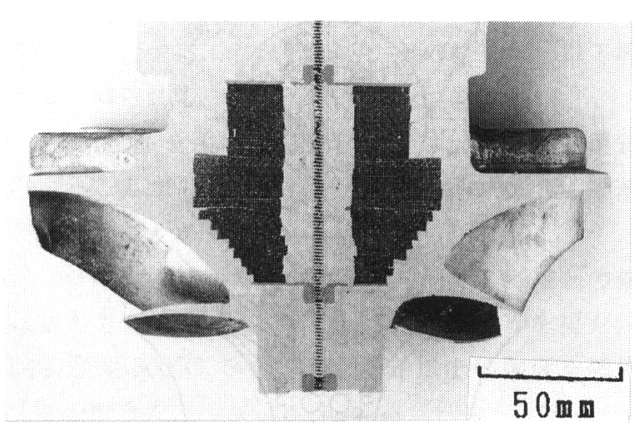

Photo. 3. Macrophotograph of cross section of alumina-fiber/aluminum composite impeller.
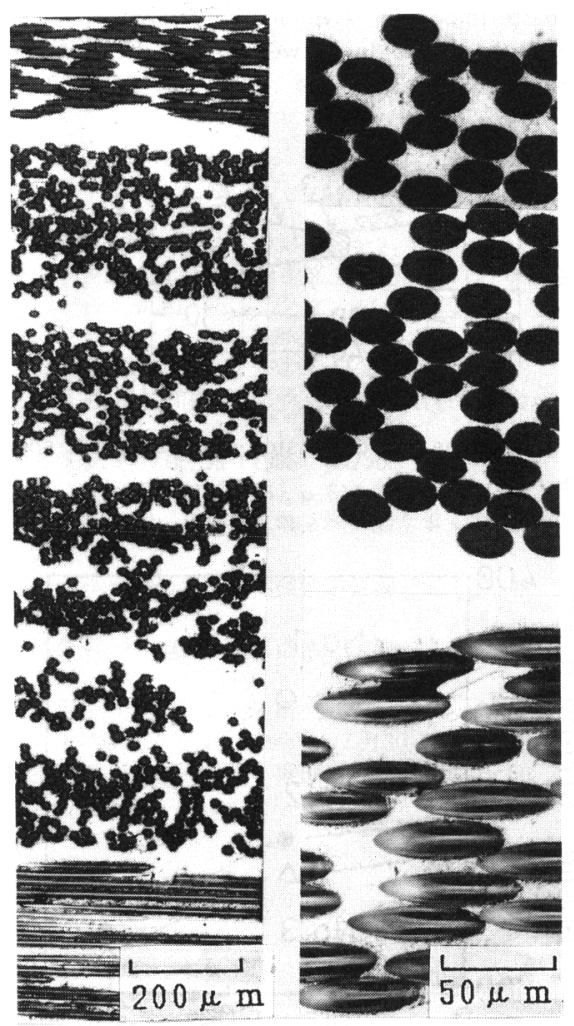

Photo. 4. Micrographs of alumina-fiber/aluminum composite of impeller.

中央部で黒く見える複合化部分を観察した状況を Photo. 4 に示す. 緎維の断面形状は $60^{\circ}$ 配列のため円 形, 棈円形, 線状となっている。纎維の含有率を, $3 \cdot 2$ と同じ条件で画像解析装置を用いて测定したところ平均 $34 \%$ であった.

試作したインペラーから引張試験片を採取し，常温お 


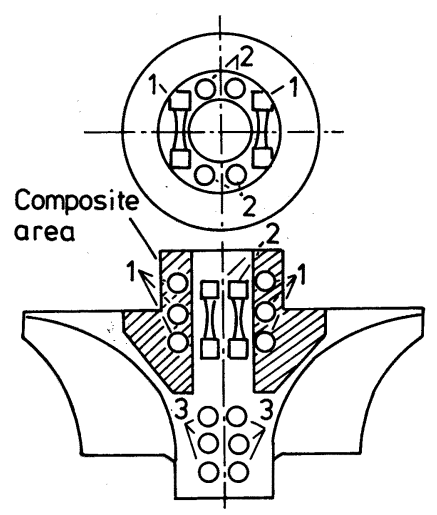

Fig. 4. Samplying positions of test specimens for composite impeller. Samples of number 1, 2 and 3 show different angle between fiber direction and tensile test load axis.

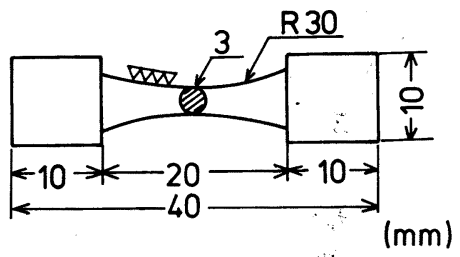

Fig. 5. Shape and dimension of tensile test specimens.

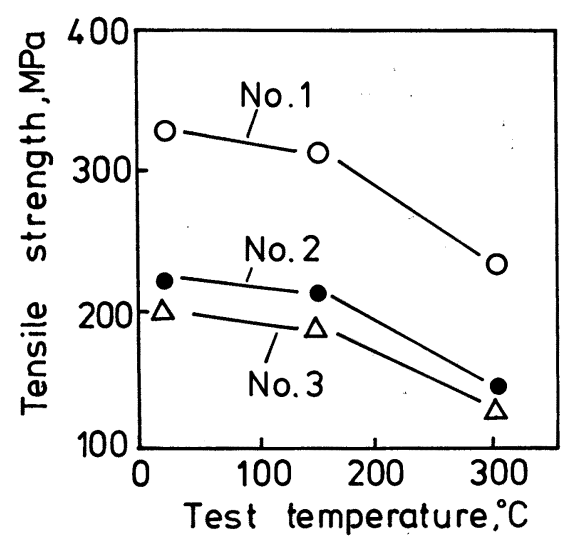

Fig. 6. Tensile strength of different position in alumina-fiber/aluminum composite impeller. The angle between fiber (laminate) direction and load direction are indicated by No. $1=0^{\circ}$, No. $2=90^{\circ}$ and No. $3=$ matrix area.

よび $150^{\circ} \mathrm{C}, 300^{\circ} \mathrm{C}$ の試験温度で各 2 本引張試験を行っ た. 試験片採取位置を Fig. 4 に, 試験片の形状を Fig. 5
に示す.

試験結果を試験温度と引張強さの平均値の関係として Fig. 6 に示す. 引張方向が䄉維の配列方向に平行な場合 （Fig. 6, No. 1）は，基地部と比較して約 $100 \mathrm{MPa}$ の引 張強さの向上が見られ, 試験温度 $300^{\circ} \mathrm{C} て ゙ も 200 \mathrm{MPa}$ 以上の引張強さを有している。，一方紛維の配列方向に直 角な方向 (Fig. 6, No. 2) では, 基地部と同じ程度の值 となっている。なお峨維との複合化部の密度は $3.00 \times 10^{3} \mathrm{~kg} / \mathrm{m}^{3}$ であった.

\section{5. 考察}

本研究ではガス加圧による複合化法を開発し，従来の 製造法よりも簡易な方法で，複雑な形状を有する小型 ジェットエンジン用の複合インペラーが製造できること を実証した．また強度面においても従来のアルミニウム 合金では実現することが難しい, 試験温度 $300^{\circ} \mathrm{C} て ゙$ $200 \mathrm{MPa}$ 以上の引張強さを実現した.

しかし実際に得られた，䄉維を一方向に配列した複合 材の引張強さは，同じ峨維を用いた溶湯鍛造法の 650 $\mathrm{MPa}$ (基地金属は $\mathrm{Al}-5 \% \mathrm{Cu}$ )に比較して約 2/3 であっ た ${ }^{10)}$.

そしてインペラーの複合化部の耐力/密度の比は最大 $10.8 \times 10^{6} \mathrm{~mm}$ と目標の約 $70 \%$ にとどまり, 当初の開 発目標を十分に満足することはできなかった。

複合インペラーが実用化されるには強度面で従来材を 凌駕することが不可欠である.そこで本研究の中で見ら れる複合材の強度阻害要因について以下のような考察を 行った.

\section{$5 \cdot 1$ 溶融金属と樴維の反応}

雲囲気加圧鋳造法では予熱温度が比較的高いため, 全 体の凝固が完了するまでのアルミナ緎維と溶融アルミニ ウム合金の接触時間が長くなり, 大気中では $1000^{\circ} \mathrm{C}$ まで安定なこの䄉維も溶湯と反応して強度が低下したこ とが考えられる、そこで純アルミニウムとアルミナ䄳維 を複合化させた試料から，10\% 塩酸により基地金属を 除去して緎維を取り出し, JIS-R-7601 の炭素䄉維試験 方法に準拠してその強度を測定した．その結果 10 本の 引張強さの平均は $1270 \mathrm{MPa}$ となり, 複合化していな い䄉維を同様に試験した時の平均引張強さ $1630 \mathrm{MPa}$ と比較して約 $30 \%$ の強度低下が確認された。

このアルミナ綫維は約 $15 \%$ の $\mathrm{SiO}_{2}$ を含むので, 界面 で次のような反応が起こり，絨維が損傷を受け強度が低 下したものと考えられる1112).

$4 \mathrm{Al}+3 \mathrm{SiO}_{2} \rightarrow 2 \mathrm{Al}_{2} \mathrm{O}_{3}+3 \mathrm{Si}$ 


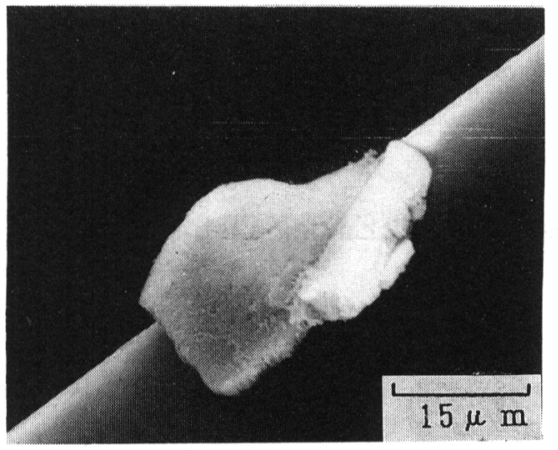

Photo. 5. Scanning electron micrograph of alumina-fiber.

\section{$5 \cdot 2$ 繊維周囲の析出物}

$\mathrm{Cu}$ を含むアルミニウム基複合材の繊維周辺に共晶と 考えられる相が析出すると, 複合材の強度低下が抏こる ことが指摘されているが13)，本実験でもそのような相 の析出が認められており, その成分組成は $\theta$ 相 $\left(\mathrm{CuAl}_{2}\right)$ と $\alpha$ 相 ( $\mathrm{Cu}$ を含む固溶体) の混合物と推定された。 ま た純アルミニウム基の複合材で，基地金属を塩酸により 除去して繊維の表面状態を観察したところ, Photo. 5 に示すような付着物も観察された.

このような析出相や付着物の形成されていく過程は明 らかではないが, 従来から指摘されているように繊維に 機械的な損傷を与え，これが応力集中部となって複合材 の強度を低下させたものと考えられる。

これらに加えて繊維間に残留した空気による空孔の存 在なども, 今回実体の強度が目標を満足できなかった原 因とも考えられる.

\section{6. 結言}

新たに開発した䨌囲気加圧鋳造法を用いて, 小型
ジェットエンジン用の複合インペラーをアルミナ繊維と アルミニウム合金により試作した。その結果は, 以下の ようにまとめられる.

（1）ガス加圧を用いた複合化法では, 精密鋳造用鋳 型を用いることが可能で, 複雑形状で大型の FRM 製部 材を製造することができる.

（2）試作したインペラーでは, アルミナ繊維との複 合化により基地金属に対し 1.5 倍の強度上昇を得た。 また試験温度 $300^{\circ} \mathrm{C}$ でも, $200 \mathrm{MPa}$ 以上の強度を確保 することができた.

（3）当初目標とした特性と実験結果との差について は, 繊維の溶湯中での劣化と繊維周囲の析出物や付着物 の影響であると推定された。

終わりに本研究の遂行に関し多大の御助力をいただい た, 住友化学工業株式会社に対して厚く感謝致します。

\section{文献}

1 ) 大藏明光: 鉄と鋼, 74 (1988), p. 413

2 ) 中川幸也: 第108, 109回西山記念技術講座（日本鉄鋼協会 編) (1985), p. 81

3 ) 西山幸夫: 鉄と鋼, 69 (1983), p. 1257

4 ) 川崎重工業株式会社カタログ (1983)

5 ) 安部康明, 藤村和稔, 堀切尚三: 日本複合材料学会誌, 6 (1980), p. 89

6 ) 福永秀春: 軽金属, 38 (1988), p. 740

7 ) 香川 豊: 鋳物, 58 (1986), p. 614

8 ) 福永秀春, 栗山 稔: 日本機械学会論文集 (C), 47 (1981), p. 1207

9 ) 福永秀春, 合田公一: 日本機械学会論文集 (C), 49 (1983), p. 1808

10）安部康明, 中谷光久, 山蔦浩治: 工業材料, 31 (1983), p. 37

11) 大藏明光, 松木理悌: 生産研究, 36 (1984), p. 429

12) 日本国特許願 105729 (1980 年 7 月30 日)

13）福永秀春, 合田公一: 日本機械学会論文集 (C), 50 (1984), p. 1054 